\title{
Naltrexone/Bupropion: An Investigational Combination for Weight Loss and Maintenance
}

\author{
Charles T. Makowski Katherine M. Gwinn Kathryn M. Hurren \\ Department of Pharmacy Practice, Eugene Applebaum College of Pharmacy and Health Science, Wayne State University, \\ Detroit, MI, USA
}

\section{Keywords}

Bupropion - Naltrexone - Obesity · Overweight . Weight loss

\section{Summary}

Naltrexone/bupropion is an investigational combination for weight loss and maintenance in patients who are obese or have a $\mathrm{BMI} \geq 27 \mathrm{~kg} / \mathrm{m}^{2}$ with comorbid diabetes, hypertension or hyperlipidemia. Pooled results from four phase 3 trials reveal placebo-subtracted mean weight loss of $4.7 \%$ (range $3.2-5.2 \%$ ) with naltrexone/ bupropion after 1 year ( $p<0.001$ vs. placebo in each trial). The placebo-subtracted proportion of patients achieving $\geq 5 \%$ weight loss with naltrexone/bupropion ranged from 26 to $33 \%$ ( $p<0.001$ vs. placebo in each trial). In the majority of phase 3 trials, naltrexone/bupropion significantly improved proportion of patients achieving $\geq 10 \%$ weight loss, waist circumference, triglycerides, high-density lipoprotein, fasting insulin, insulin resistance, and obesity-specific quality of life compared to placebo. In patients with diabetes, naltrexone/ bupropion therapy decreased hemoglobin $\mathrm{A} 1 \mathrm{c}(\mathrm{HbA} 1 \mathrm{c})$ approximately $0.5 \%$ more than placebo $(p<0.001)$. Common side effects associated with naltrexone/bupropion include nausea, constipation, vomiting, dizziness, and dry mouth. Greater improvement in systolic blood pressure and pulse were seen with placebo compared to naltrexone/bupropion $(p<0.001)$. Further studies are necessary to determine the effect of naltrexone/bupropion on cardiovascular outcomes. The safety and efficacy of naltrexone/bupropion in weight management is reviewed in this article.

\section{Introduction}

An estimated $34 \%$ of American adults were obese, and an additional 34\% were overweight in 2007-2008 [1]. Obesity is associated with diabetes, hypertension, hyperlipidemia, stroke, heart disease, respiratory problems, osteoarthritis, and several types of cancer [2]. Across all insurance sectors medical spending for an obese patient is approximately $42 \%$ higher annually compared to that for an individual with normal body weight [3].

Sustained loss of $5-10 \%$ of baseline body weight improves several cardiovascular risk factors, including hypertension, dyslipidemia, insulin resistance, and diabetes [4]. Caloric restriction, exercise, and behavioral modification are the cornerstones of weight management. When lifestyle interventions are unsuccessful, adjunct pharmacotherapy may be considered. The only medication currently approved for longterm weight loss and maintenance is orlistat. Noradrenergic appetite suppressants, such as phentermine, are marketed for short-term use only, a strategy that is not recommended for weight loss [2].

A medication that provides ample weight loss, improves cardiovascular risk, and is associated with an acceptable safety and side effect profile could benefit a widespread patient population. To be considered effective, weight loss medications must meet one of the following 1-year benchmarks outlined by the US Food and Drug Administration (FDA) [5]:

- The difference in mean weight loss between the activeproduct and placebo-treated groups is at least $5 \%$, and the difference is statistically significant.

- The proportion of subjects who lose greater than or equal to $5 \%$ of baseline body weight in the active-product group is at least $35 \%$, is approximately double the proportion in the placebo-treated group, and the difference between groups is statistically significant.

\section{KARGER \\ Fax +497614520714 \\ Information@Karger.de}

www.karger.com
(C) 2011 S. Karger GmbH, Freiburg

$1662-4025 / 11 / 0046-0489 \$ 38.00 / 0$

Accessible online at:

www.karger.com/ofa
Kathryn Hurren, Pharm.D.

Department of Pharmacy Practice

Eugene Applebaum College of Pharmacy and Health Science, Wayne State University

259 Mack Avenue, Suite 2190, Detroit, MI 48201, USA

Tel. +1 313-3433628, Fax -5775369

k.hurren@wayne.edu 
Table 1. Pharmacokinetics of naltrexone SR and bupropion SR

\begin{tabular}{|c|c|c|c|c|}
\hline & Absorption & Distribution & Metabolism & Elimination \\
\hline Naltrexone SR [7, 13] & almost complete & $21 \%$ protein binding & $\begin{array}{l}\text { hepatic via dihydrodioldihydrogenase and } \\
\text { conjugation to 6-beta-naltrexol (active) } \\
\text { extensive first-pass metabolism }\end{array}$ & $\begin{array}{l}\mathrm{T}_{1 / 2}=5 \mathrm{~h} \\
\text { primarily excreted in urine }\end{array}$ \\
\hline Bupropion SR [8] & rapid, complete & $84 \%$ protein binding & $\begin{array}{l}\text { hepatic metabolism via CYP2B6 to } \\
\text { hydroxybupropion (active) } \\
\text { non-CYP metabolism to } \\
\text { erythrohydrobupropion (active) and } \\
\text { threohydrobupropion (active) }\end{array}$ & $\begin{array}{l}\mathrm{T}_{1 / 2}=21 \mathrm{~h} \\
\text { with chronic dosing } \\
\text { urine: } 87 \% \\
\text { feces: } 10 \%\end{array}$ \\
\hline
\end{tabular}

A challenge to achieving these benchmarks lies in the body's mechanisms to maintain energy homeostasis. Caloric restriction and weight loss lead to neurohormonal adjustments which increase food intake and favor weight regain [6]. Thus, synergistic medication combinations for weight loss hold particular promise.

Naltrexone/bupropion (Contrave ${ }^{\circledR}$; Orexigen Therapeutics, Inc., La Jolla, CA, USA) is an investigational combination therapy being studied for weight loss and maintenance in patients who are obese $\left(\mathrm{BMI} \geq 30 \mathrm{~kg} / \mathrm{m}^{2}\right)$ or have a BMI of $\geq 27 \mathrm{~kg} / \mathrm{m}^{2}$ with comorbidities of diabetes, hypertension, or hyperlipidemia. Naltrexone is indicated in alcohol and opioid dependence with a usual dose of $50 \mathrm{mg}$ daily [7]. Bupropion is approved for the treatment of major depressive disorder, seasonal affective disorder, and smoking cessation assistance and is typically given in $300 \mathrm{mg}$ daily doses [8]. Both agents have been marketed in the USA since 1985 as monotherapy.

The FDA Advisory Committee voted 13:7 to approve naltrexone/bupropion on December 7, 2010 [9]. However, the FDA did not grant approval and requested a randomized controlled trial be conducted to assess cardiovascular events before the New Drug Application (NDA) is resubmitted [10]. On June 3, 2011, The manufacturer plans to initiate the study which could lead to approval in 2014 [11]. The purpose of this article is to review the pharmacology, efficacy, and safety of naltrexone/bupropion, an investigational combination for weight management.

\section{Pharmacology}

Naltrexone is a pure opioid antagonist [7,12]. Bupropion is a weak inhibitor of the neuronal reuptake of norepinephrine and dopamine [8]. These catecholamines stimulate pro-opiomelanocortin (POMC) neurons in the arcuate nucleus of the hypothalamus [12]. POMC is a precursor for $\alpha$-melanocyte stimulating hormone $(\alpha-\mathrm{MSH})$ and $\beta$-endorphin. $\alpha$-MSH acts on melanocortin-4 receptors to decrease food intake, whereas $\beta$-endorphin sends feedback inhibition to POMC neurons, decreasing this effect. Bupropion has limited weight loss efficacy as monotherapy likely due to this autoinhibitory feedback. As an opioid antagonist, naltrexone suppresses the negative feedback from $\beta$-endorphin. In vitro, bupropion and naltrexone monotherapy reversibly increased the frequency of action potentials to approximately $3-4 \mathrm{~Hz}$ in mouse POMC neurons [12]. However, combined application of bupropion and naltrexone increased POMC firing to approximately $11 \mathrm{~Hz}$. Naltrexone/bupropion may also modulate food cravings through an effect on the dopamine reward pathway, as evidenced by improved responses to the question 'generally, how difficult has it been to control your eating?' on the Control of Eating questionnaire administered in all phase 3 trials [13].

\section{Pharmacokinetics}

The pharmacokinetics of naltrexone and bupropion are displayed in table 1. Naltrexone is reformulated as a sustained release (SR) dosage form in this combination product, which has bioequivalent exposure to naltrexone immediate release (IR) $[13,14]$.

Naltrexone/bupropion should be used with caution in patients who are elderly or have moderate or severe renal impairment. It should be avoided in patients with severe hepatic disease [7].

\section{Clinical Studies}

The clinical efficacy of naltrexone/bupropion was compared to each monotherapy and placebo in a multicenter, randomized, double-blind, phase 2 clinical trial [15]. A total of 419 subjects with uncomplicated obesity were randomized to receive either bupropion SR $400 \mathrm{mg} /$ day plus naltrexone IR $16 \mathrm{mg} /$ day, $32 \mathrm{mg} /$ day, or $48 \mathrm{mg} /$ day; bupropion SR $400 \mathrm{mg} /$ day; naltrexone IR $48 \mathrm{mg} /$ day; or placebo. After 24 weeks the naltrexone monotherapy and placebo groups were discontinued with $1.2 \%$ and $0.8 \%$ body weight loss, respectively. After 48 weeks bupropion monotherapy and bupropion plus naltrexone $16 \mathrm{mg} /$ day, $32 \mathrm{mg} /$ day and $48 \mathrm{mg} /$ day produced mean weight losses of $2.7 \%, 5.0 \%, 5.5 \%$, and $6.6 \%$, respectively ( $p<0.05$ for all combinations vs. monotherapy). Higher attri- 
Table 2. Study design, population characteristics and results for phase 3 trials of naltrexone/bupropion*

\begin{tabular}{|c|c|c|c|c|c|}
\hline Reference & Design & $\begin{array}{l}\text { Treat- } \\
\text { ment }\end{array}$ & $\begin{array}{l}\text { Mean age (years) / } \\
\text { female sex }(\%) / \\
\text { Caucasian }(\%) / \\
\text { BMI }\left(\mathrm{kg} / \mathrm{m}^{2}\right)\end{array}$ & Primary results & $\begin{array}{l}\text { Secondary results } \\
\text { (NB32 vs. PBO) }\end{array}$ \\
\hline Greenway [16] & $\begin{array}{l}56 \text { weeks } \\
\text { MC, } R, \\
\text { DB, PC } \\
N=1,742\end{array}$ & $\begin{array}{l}\text { 1:1:1 } \\
\text { NB16 } \\
\text { NB32 } \\
\text { PBO }\end{array}$ & $44 / 85 / 75 / 36$ & $\begin{array}{l}\text { change in weight }(\%) \\
\text { NB16: }-5.0^{\mathrm{a}} \\
\text { NB32: }-6.1^{\mathrm{a}} \\
\text { PBO: }-1.3 \\
\geq 5 \% \text { weight loss }(\%) \\
\text { NB16: } 39^{\mathrm{a}} \\
\text { NB32: } 48^{\mathrm{a}} \\
\text { PBO: } 16\end{array}$ & $\begin{array}{l}\geq 10 \% \text { weight loss }(\%): 25 \text { vs. } 7^{\mathrm{a}} \\
\geq 15 \% \text { weight loss }(\%): 12 \text { vs. } 2^{\mathrm{a}} \\
\text { change in: } \\
\text { waist }(\mathrm{cm}):-6.2 \text { vs. }-2.5^{\mathrm{a}} \\
\text { triglycerides }(\%):-12.7 \text { vs. }-3.1^{\mathrm{a}} \\
\text { HDL }(\mathrm{mg} / \mathrm{dl}): 3.5 \text { vs. } 0.0^{\mathrm{a}} \\
\text { LDL }(\mathrm{mg} / \mathrm{dl}):-4.3 \text { vs. }-3.1^{\mathrm{b}} \\
\text { HsCRP }(\%):-29.0 \text { vs. }-16.7^{\mathrm{c}} \\
\text { FBG }(\mathrm{mg} / \mathrm{dl}):-3.2 \text { vs. }-1.3^{\mathrm{c}} \\
\text { fasting insulin }(\%):-17.1 \text { vs. }-4.6 \\
\text { HOMA } \\
\text { IW }(\%):-20.2 \text { vs. }-5.9 \\
\text { IWQO-Lite score: } 12.7 \text { vs. } 8.6^{\mathrm{a}}\end{array}$ \\
\hline $\begin{array}{l}\text { Hollander } \\
\text { abstract [19] } \\
\text { FDA Advisory [13] }\end{array}$ & $\begin{array}{l}56 \text { weeks, } \\
\text { MC, } R, \\
\text { DB, PC } \\
N=505\end{array}$ & $\begin{array}{l}2: 1 \\
\text { NB32 } \\
\text { PBO }\end{array}$ & $\begin{array}{l}\text { 54/54/80/37 } \\
\text { Baseline HbA1c: } \\
8.0 \%\end{array}$ & $\begin{array}{l}\text { change in weight (\%) } \\
\text { NB32: }-5.0 \\
\text { PBO: }-1.8 \\
\geq 5 \% \text { weight loss (\%) } \\
\text { NB32: } 45 \\
\text { PBO: } 19\end{array}$ & $\begin{array}{l}\geq 10 \% \text { weight loss (\%): } 19 \text { vs. } 6 \\
\text { HbA1c }<7.0 \%(\%): 44 \text { vs. } 26 \\
\text { HbA1c }<6.5 \%(\%): 21 \text { vs. } 10^{\mathrm{c}} \\
\text { change in: } \\
\text { HbA1c }(\%):-0.63 \text { vs. }-0.14 \\
\text { waist }(\mathrm{cm}):-5.0 \text { vs. }-2.9^{\mathrm{c}} \\
\text { triglycerides }(\%):-11.2 \text { vs. }-0.8^{\mathrm{c}} \\
\text { HDL (mg/dl): } 3.0 \text { vs. }-0.3 \\
\text { LDL }(\mathrm{mg} / \mathrm{dl}):-1.4 \text { vs. } 0.0^{\mathrm{b}} \\
\text { HsCRP }(\%):-20.9 \text { vs. }-13.3^{\mathrm{b}} \\
\text { FBG }(\mathrm{mg} / \mathrm{dl}):-11.9 \text { vs. }-4.0^{\mathrm{b}} \\
\text { fasting insulin: }-13.5 \text { vs. }-10.4^{\mathrm{b}} \\
\text { HOMA }{ }_{\text {IR }}(\%):-20.6 \text { vs. }-14.7^{\mathrm{b}} \\
\text { IWQOL-Lite score: } 9.3 \text { vs. } 7.9^{\mathrm{b}}\end{array}$ \\
\hline $\begin{array}{l}\text { Rubino abstract [18] } \\
\text { FDA Advisory [13] }\end{array}$ & $\begin{array}{l}56 \text { weeks, } \\
\text { MC, } R, \\
\text { DB, PC } \\
\mathrm{N}=1,496\end{array}$ & $\begin{array}{l}2: 1 \\
\text { NB32 } \\
\text { PBO }\end{array}$ & $44 / 84 / 85 / 36$ & $\begin{array}{l}\text { change in weight }(\%) \\
\text { NB32: }-6.4 \\
\text { PBO: }-1.2 \\
\geq 5 \% \text { weight loss (\%) } \\
\text { NB32: } 51 \\
\text { PBO: } 17\end{array}$ & $\begin{array}{l}\geq 10 \% \text { weight loss ( } \%): 28 \text { vs. } 6 \\
\text { change in: } \\
\text { waist }(\mathrm{cm}):-6.7 \text { vs. }-2.1 \\
\text { triglycerides (\%): }-9.8 \text { vs. }-0.5 \\
\text { HDL }(\mathrm{mg} / \mathrm{dl}): 3.6 \text { vs. }-0.9 \\
\text { LDL }(\mathrm{mg} / \mathrm{dl}):-6.2 \text { vs. }-2.1^{\text {c }} \\
\text { HsCRP }(\%):-28.8 \text { vs. }-8.3 \\
\text { FBG }(\mathrm{mg} / \mathrm{dl}):-2.8 \text { vs. }-1.3^{\text {b }} \\
\text { fasting insulin }(\%):-11.4 \text { vs. } 3.5 \\
\text { HOMA }{ }_{\text {IR }}(\%):-13.8 \text { vs. } 1.2 \\
\text { IWQOL-Lite score: } 10.9 \text { vs. } 6.4\end{array}$ \\
\hline Wadden [17] & $\begin{array}{l}56 \text { weeks, } \\
\text { MC, R, } \\
\text { DB, PC } \\
N=793\end{array}$ & $\begin{array}{l}1: 3 \\
\text { NB32 } \\
+ \text { BMOD } \\
\text { PBO } \\
+ \text { BMOD }\end{array}$ & 46/90/70/37 & $\begin{array}{l}\text { change in weight }(\%) \\
\text { NB32+BMOD: }-9.3 \\
\text { PBO+BMOD: }-5.1 \\
\geq 5 \% \text { weight loss (\%) } \\
\text { NB32+BMOD: } 66 \\
\text { PBO+BMOD: } 43\end{array}$ & 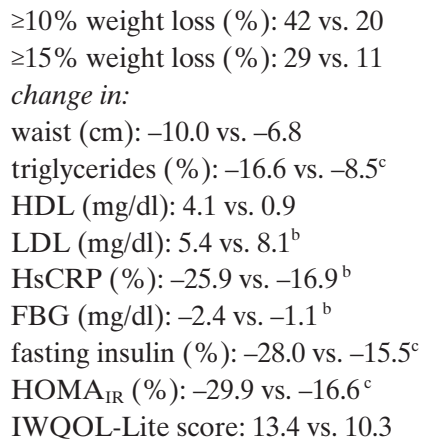 \\
\hline
\end{tabular}

$\mathrm{BMOD}=$ Behavioral modification; $\mathrm{DB}=$ double-blind; FBG = fasting blood glucose; HbA1c = hemoglobin A1c; HDL = high-density lipoprotein; $\mathrm{HOMA}_{\mathrm{IR}}=$ homeostasis model assessment for insulin resistance; hsCRP = high-sensitivity C-reactive protein; IWQOL = Impact of Weight on Quality of Life; LDL = low-density lipoprotein; $\mathrm{MC}$ = multicenter; NB16 = naltrexone $16 \mathrm{mg}$ plus bupropion; NB32 = naltrexone $32 \mathrm{mg}$ plus bupropion; $\mathrm{PBO}=$ placebo $\mathrm{PC}=$ placebo-controlled $\mathrm{R}=$ randomized $; \mathrm{wk}=$ week $; \mathrm{yr}=$ year.

$* \mathrm{p}<0.001$ for all comparisons between naltrexone/bupropion and placebo except where noted. ${ }^{\mathrm{a}} \mathrm{p}<0.0001$.

${ }^{\mathrm{b}}$ Not significant.

${ }^{c} \mathrm{p}<0.05$. 
tion rates were observed in the bupropion plus naltrexone $48 \mathrm{mg} /$ day group (73\%) compared to the bupropion plus naltrexone $16 \mathrm{mg} /$ day and $32 \mathrm{mg} /$ day groups $(52 \%$ and $46 \%$, respectively). Early discontinuation during the first 24 weeks accounted for most cases, with adverse events and lost to follow-up cited as the most common reasons.

The Contrave Obesity Research (COR) Program consists of four phase 3 trials: COR-I, COR-II, COR-Behavioral Modification (COR-BMOD), and COR-Diabetes Mellitus (COR$\mathrm{DM})$. The study designs, population characteristics, and results are displayed in table 2. All studies were designed and sponsored by Orexigen Therapeutics, Inc. The COR-I, CORII, and COR-BMOD studies included patients who were $18-65$ years of age with a BMI of $30-45 \mathrm{~kg} / \mathrm{m}^{2}$ without comorbidities or a BMI of $27-45 \mathrm{~kg} / \mathrm{m}^{2}$ with controlled hypertension and/or dyslipidemia [13, 16-18]. Patients were excluded if they had diabetes. The COR-DM study included patients with a BMI of $27-45 \mathrm{~kg} / \mathrm{m}^{2}$ who were $18-70$ years of age, were diagnosed with type 2 diabetes (hemoglobin A1c (HbA1c) $7-10 \%$ ), and were not prescribed insulin $[13,19]$. All trials excluded patients with type 1 diabetes; cerebrovascular, cardiovascular, hepatic, renal, or psychiatric disease; previous surgical or device intervention for obesity; seizure disorder; or recent history of drug or alcohol dependence [13]. Co-primary endpoints in the COR Program were percentage change in body weight and proportion of participants with a decrease in body weight of at least $5 \%$ from baseline at week 56 .

COR-I, COR-II, and COR-DM trial participants received lifestyle counseling at baseline and every 12 weeks $[13,16]$. Lifestyle recommendations included decreasing energy consumption by $500 \mathrm{kcal} /$ day and increasing physical activity. Participants in the COR-BMOD trial attended 90-min multidisciplinary group visits weekly for 16 weeks and monthly thereafter [17]. Subjects were prescribed 1,200-2,000 kcal/day diets based on initial body weight and encouraged to engage in physical activity for $180 \mathrm{~min} /$ week for the first 6 months, increasing to $360 \mathrm{~min} /$ week thereafter.

Results from the COR-II trial met the first FDA efficacy benchmark for mean percent weight loss. The COR-I, COR-II, and COR-DM trials met the second FDA efficacy benchmark for proportion of subjects with at least $5 \%$ weight loss. In the majority of phase 3 studies, treatment with naltrexone/bupropion resulted in significant improvement in percentage of patients achieving $\geq 10 \%$ weight loss, waist circumference, triglycerides, high-density lipoprotein (HDL), fasting insulin, insulin resistance, and obesity-specific quality of life as assessed through the Impact of Weight on Quality of Life-Lite questionnaire.

\section{Adverse Effects}

Nausea (33 vs. $7 \%$ ), constipation (19 vs. $7 \%$ ), headache (18 vs. $10 \%$ ), vomiting (11 vs. $3 \%$ ), dizziness (10 vs. $3 \%$ ), insom- nia ( 9 vs. $6 \%$ ), dry mouth ( 8 vs. $2 \%$ ), and diarrhea (7\% vs. $5 \%$ ) were common side effects that occurred more frequently with naltrexone/bupropion than placebo [13]. Tremor, hot flush, tinnitus, upper abdominal pain, and hyperhidrosis occurred in approximately $3-4 \%$ of patients treated with naltrexone/bupropion and $1 \%$ of patients treated with placebo. In pooled phase 3 trials, adverse effects led to discontinuation in $24 \%$ of the naltrexone/bupropion group and $12 \%$ of the placebo group. Nausea, headache, dizziness, and vomiting were the most frequent adverse effects leading to discontinuation. Serious adverse effects were infrequent and equally distributed among treatment groups (2.5 vs. 1.7\%), except more patients receiving naltrexone/bupropion experienced cholecystitis/cholelithiasis (0.3 vs. $0.07 \%)$. Depression-related events occurred in $2.9 \%$ of the naltrexone/bupropion group and $3.4 \%$ of the placebo group. Three patients assigned to naltrexone/bupropion had a myocardial infarction $(0.12 \%)$, but overall cardiac disorders did not differ between groups $(0.2$ vs. $0.3 \%)$. Two patients $(0.06 \%)$ had a seizure while assigned to naltrexone/bupropion therapy.

Greater improvement in blood pressure and pulse were seen with placebo compared to naltrexone/bupropion [13]. After 56 weeks of treatment in pooled phase 3 trials, change in systolic blood pressure (SBP) from baseline was $-0.86 \mathrm{~mm}$ $\mathrm{Hg}$ and $-2.33 \mathrm{~mm} \mathrm{Hg}$ with naltrexone/bupropion and placebo, respectively $(\mathrm{p}<0.001)$. The 56 -week change in diastolic blood pressure (DBP) was $-1.01 \mathrm{~mm} \mathrm{Hg}$ and $-1.50 \mathrm{~mm} \mathrm{Hg}$, respectively $(p=0.08)$. The between-group differences for SBP and DBP were the greatest after 8 weeks of treatment. Hypertension was reported as an adverse event in $5.3 \%$ of patients assigned naltrexone/bupropion and $4.0 \%$ of those assigned placebo. At week 56, change in pulse from baseline was 0.3 beats per minute (bpm) versus $-0.98 \mathrm{bpm}$ with naltrexone/bupropion and placebo, respectively $(\mathrm{p}<0.001)$. Tachycardia occurred at a rate of $0.6 \%$ with naltrexone/bupropion and $0.2 \%$ with placebo. The greatest between-group difference for pulse occurred at week 24. Patients who lost at least $5 \%$ body weight with naltrexone/bupropion had a similar change in blood pressure and pulse compared to those who did not achieve $5 \%$ weight loss with placebo.

\section{Drug Interactions}

Bupropion is metabolized by CYP2B6 and inhibits CYP2D6 $[8,13]$. Medications that induce CYP2B6, including lopinavir/ ritonavir, rifampin, carbamazepine, phenytoin and phenobarbital, may decrease the effect of bupropion. Medications that inhibit CYP2B6 are not expected to increase the effects of bupropion due to its multiple metabolic pathways [13]. Bupropion may increase the effect of CYP2D6 substrates, including selective serotonin reuptake inhibitor and tricyclic antidepressants, venlafaxine, antipsychotics, metoprolol, propafenone, and flecainide. Bupropion is contraindicated with concomi- 
tant monoamine oxidase inhibitors and should not be used with medications that lower the seizure threshold [8]. Naltrexone should not be used in patients using opioid analgesics [7].

\section{Dosage and Administration}

Naltrexone/bupropion is formulated as $4 / 90 \mathrm{mg}$ and $8 / 90 \mathrm{mg}$ tablets [13]. One 4/90 mg tablet daily may be considered as a conservative initial dose. The recommended initial dose titration schedule for $8 / 90 \mathrm{mg}$ tablets is as follows: one tablet in the morning for week 1 , one tablet twice daily for week 2 , two tablets in the morning and one in the evening for week 3 , and two tablets twice daily starting on week 4 . The maintenance dose is $16 \mathrm{mg}$ of naltrexone SR and $180 \mathrm{mg}$ of bupropion SR (taken as two $8 / 90 \mathrm{mg}$ tablets) twice daily. It can be taken with or without food.

\section{Future Application}

Naltrexone/bupropion is an investigational combination for weight management. It is being developed as an adjunct to lifestyle modification for weight loss and maintenance in patients who are obese or have a BMI of $\geq 27 \mathrm{~kg} / \mathrm{m}^{2}$ with obesityrelated disease (e.g. diabetes, dyslipidemia, or hypertension). The agent is also currently in phase 3 trials for smoking cessation. Pooled results from four phase 3 trials reveal placebosubtracted mean weight loss of $4.7 \%$ with naltrexone/bupropion [13]. The placebo-subtracted proportion of patients achieving $\geq 5 \%$ weight loss with naltrexone/bupropion ranged from 26 to $33 \%$.

Naltrexone/bupropion has not been studied in head-to-head comparison with other medications for weight management. The lipase inhibitor orlistat is currently the only medication FDA approved for long-term weight management. In October 2010, the FDA denied approval of the investigational serotonin 2C agonist lorcaserin (Lorqess ${ }^{\circledR}$, Arena Pharmaceuticals, San Diego, CA, USA) and combination phentermine/topiramate (Qnexa ${ }^{\circledR}$, Vivus Pharmaceuticals, Mountain View, CA, USA) for weight management $[20,21]$. Additional information about carcinogenicity in rats with lorcaserin and teratogenicity and cardiovascular risk with phentermine/topiramate was requested prior to resubmission of the NDAs. Placebo-controlled trials of individual agents suggest that naltrexone/bupropion has greater weight loss efficacy than orlistat or lorcaserin, but is less effective than phentermine/topiramate. Prescription dose orlistat results in approximately $2.9 \%$ placebo-subtracted body weight loss, and $21 \%$ more subjects attained $\geq 5 \%$ weight loss with orlistat compared to placebo [22]. Patients assigned to lorcaserin $10 \mathrm{mg}$ twice daily lost approximately $2.5 \%$ more body weight compared to placebo, and $25 \%$ more patients achieved $\geq 5 \%$ weight loss in phase 3 trials [23, 24]. Mediumdose $(7.5 / 46 \mathrm{mg})$ and high-dose $(15 / 92 \mathrm{mg})$ phentermine/topira- mate produced an additional $6.9 \%$ and $8.9 \%$ body weight loss, respectively, compared to placebo, and $43 \%$ or $49 \%$ more patients achieved $\geq 5 \%$ weight loss in phase 3 trials [25].

Naltrexone/bupropion therapy resulted in common side effects expected of the individual components. Orlistat is associated with gastrointestinal side effects, and severe liver injury has been reported rarely with its use [22, 26]. Lorcaserin was generally well-tolerated, with the most common adverse effects being nausea, vomiting, headache, and dizziness [23, 24]. The most common dose-related adverse effects associated with phentermine/topiramate were paresthesia, dry mouth, constipation, dysgeusia, dizziness, and insomnia [25]. Proposed dosing is once daily for phentermine/topiramate, twice daily for bupropion/naltrexone and lorcaserin, and thrice daily for orlistat.

Naltrexone/bupropion treatment resulted in significant improvement in several cardiometabolic risk factors, including waist circumference, triglycerides, and HDL [13]. Lowdensity lipoprotein and C-reactive protein were improved, but differences did not reach significance in all trials. Compared to placebo, naltrexone/bupropion significantly improved fasting insulin and insulin resistance in patients without diabetes and reduced $\mathrm{HbA} 1 \mathrm{c} 0.5 \%$ in patients with diabetes. The effect of naltrexone/bupropion on cardiometabolic risk factors is consistent with the benefits of clinically meaningful weight loss; however, the improvement in blood pressure and pulse were attenuated.

The effect of weight loss agents on blood pressure and pulse is an important consideration. Recently, the noradrenergic/serotonergic appetite suppressant sibutramine was removed from the market due to an increased risk of cardiovascular events in high-risk patients [27]. Compared to placebo, sibutramine therapy increased SBP by $1.7 \mathrm{~mm} \mathrm{Hg}$, DBP by $2.4 \mathrm{~mm} \mathrm{Hg}$, and pulse by $4.5 \mathrm{bpm} \mathrm{[22].} \mathrm{Naltrexone/bupropion}$ therapy decreased SBP and DBP with differences of approximately 1.5 and $0.5 \mathrm{~mm} \mathrm{Hg}$, respectively, compared to placebo. Naltrexone/bupropion increased heart rate by approximately $1 \mathrm{bpm}$ compared to placebo. Providers should consider discontinuation of naltrexone/bupropion in patients who do not achieve $\geq 5 \%$ weight loss after 4 months of therapy or who experience clinically relevant and sustained increases in blood pressure or pulse [13].

\section{Conclusion}

Based on a review of the available data, naltrexone/bupropion is an effective agent for weight management. Further studies are necessary to determine the effect of naltrexone/ bupropion on cardiovascular outcomes.

\section{Disclosure Statement}

The authors have no conflicts of interest to disclose. 


\section{References}

1 Flegal KM, Carroll MD, Ogden CL, Curtis LR Prevalence and trends in obesity among US adults, 1999-2008. JAMA 2010;303:235-241.

2 National Institutes of Health: Clinical guidelines on the identification, evaluation, and treatment of overweight and obesity in adults: the evidence report. Obes Res 1998;6(suppl 2):51S-209S.

$\checkmark 3$ Finkelstein EA, Trogdon JG, Cohen JW, Dietz W: Annual medical spending attributable to obesity: payer-and service-specific estimates. Health Aff (Millwood) 2009;28:822-831.

4 Klein S: Outcome success in obesity. Obes Res 2001;9(suppl 4):354S-358S

5 U.S. Food and Drug Administration: Guidance for Industry Developing Products for Weight Management: Draft Guidance. www.fda.gov/downloads/ Drugs/GuidanceComplianceRegulatoryInformation/ Guidances/ucm071612.pdf, accessed November 29, 2011.

6 Morton GJ, Cummings DE, Baskin DG, Barsh GS Schwartz MW: Central nervous system control of food intake and body weight. Nature 2006;443:289295.

7 Naltrexone Hydrocholoride Package Insert. Hazelwood, Mallinckrodt Inc., February 2009.

8 Drugdex evaluations [online]. Bupropion. Micromedex 2.0, Thompson Reuters, 1974-2011.

9 Wood S: Most FDA advisors say likely benefits of Contrave diet drug outweigh its cardiovascular risks. www.theheart.org/article/1160743.do, accessed November 29, 2011.

10 Wood S: FDA declines approval for Contrave diet drug; asks for CVD outcomes studies. www.theheart. org/article/1179441.do, accessed November 29, 2011.

11 PRNewswire; orexigen and FDA identify a clear and feasible path to approval for Contrave. http://ir.orexigen.com/phoenix.zhtml? c $=207034$ \& $p=$ irol-news Article \&ID=160857\&highlight $=$, accessed December 5, 2011.

12 Greenway FL, Whitehouse MJ, Guttadauria M, Anderson JW, Atkinson RL, Fujioka K, Gadde KM, Guptka AK, O’Neil P, Schumacher D, Smith D, Dunayevich E, Tollefson GD, Weber E, Cowley MA: Rational design of a combination medication for the treatment of obesity. Obesity (Silver Spring) 2009;17:30-39.
13 U.S. Food and Drug Administration. Contrave (naltrexone SR/bupropion SR combination): Advisory Committee briefing document, December 7, 2010. www.fda.gov/downloads/AdvisoryCommittees/CommitteesMeetingMaterials/Drugs/EndocrinologicandMetabolicDrugsAdvisoryCommittee/ UCM235672.pdf, accessed November 29, 2011.

14 Grundy J, Dunayevich E, Guttadauria M, Dunzo E, McKinney A, Tollefson G: Relative bioavailability of sustained-release (SR) versus immediaterelease (IR) naltrexone (NAL) formulations in healthy obese volunteers: implications for improved tolerability(585-P). Obesity 2008;16(suppl 1):S217.

15 Greenway FL, Dunayevich E, Tollefson G, Erickson J, Guttadauria M, Fujioka K, Cowley MA: Comparison of combined bupropion and naltrexone therapy for obesity with monotherapy and placebo. J Clin Endocrinol Metab 2009;94:4898-4906.

16 Greenway FL, Fujioka K, Plodkowski RA, Mudaliar S, Guttadauria M, Erickson J, Kim DD, Dunayevich E: Effect of naltrexone plus bupropion on weight loss in overweight and obese adults (COR-I): a multicentre, randomised, double-blind, placebo-controlled, phase 3 trial. Lancet 2010;376: 595-605.

17 Wadden TA, Foreyt JP, Foster GD, Hill JO, Klein S, O'Neil PM, Perri MG, Pi-Sunyer FX, Rock CL, Erickson JL, Maier HN, Kim DD, Dunayevich E: Weight loss with naltrexone SR/bupropion SR combination therapy as an adjunct to behavior modification: The COR-BMOD trial. Obesity (Silver Spring) 2011;19:110-120

18 Rubino D, Apovian CM, Still CD, Mignon L, Burns C, Harris-Collazo R, Dunayevich E: Naltrexone SR/bupropion SR combination (NB) therapy shifts subjects from the obese to the non-obese body mass index(BMI) classes: From the COR-II phase 3, double-blind, placebo-controlled, 56-week study (499-P). Obesity 2008;16(suppl 1):S192.

19 Hollander P, Plodkowski R, Gupta AK, Guttadauria M, Erickson J, Kim D, Dunayevich E: CORDiabetes: Naltrexone SR/bupropion SR combination therapy led to significant and sustained weight loss and improved $\mathrm{HbA} 1 \mathrm{c}$ in overweight/obese subjects with type 2 diabetes (56-OR). Paper presented at the American Diabetes Association 70th Scientific Sessions. Orlando, FL, June 25, 2010.
20 Wood S: Obesity drug lorcaserin rejected by FDA. www.theheart.org/article/1140283.do, accessed November 29, 2011.

21 Miller R: FDA rejects Qnexa, asks for more info www.theheart.org/article/1142017.do, accessed November 29, 2011.

22 Rucker D, Padwal R, Li SK, Curioni C, Lau DC: Long term pharmacotherapy for obesity and overweight: updated meta-analysis. BMJ 2007;335: 1194-1199.

23 Smith SR, Weissman NJ, Anderson CM, Sanchez M, Chuang E, Stubbe S, Bays H, Shanahan WR: Multicenter, placebo-controlled trial of lorcaserin for weight management. N Engl J Med 2010;363: 245-256.

24 U.S. Food and Drug Administration Endocrinologic and Metabolic Drugs Advisory Committee: FDA briefing document: NDA 22529, Lorqess (lorcaserin hydrochloride) tablets. www.fda.gov/ downloads/AdvisoryCommittees/CommitteesMeetingMaterials/Drugs/EndocrinologicandMetabolicDrugsAdvisoryCommittee/UCM225631.pdf accessed November 29, 2011.

25 U.S. Food and Drug Administration Endocrinologic and Metabolic Drugs Advisory Committee: Clinical briefing document: NDA 22580, VI-0521 QNEXA (phentermine/topiramate).www.fda.gov/ downloads/AdvisoryCommittees/Committees MeetingMaterials/Drugs/Endocrinologicand MetabolicDrugsAdvisoryCommittee/UCM218824. pdf, accessed November 29, 2011.

26 U.S. Food and Drug Administration: FDA drug safety communication: Completed safety review of Xenical/Alli (orlistat) and severe liver injury. $w w w$. fda.gov/Drugs/DrugSafety/PostmarketDrugSafetyInformationforPatientsandProviders/ucm 213038. htm, accessed November 29, 2011.

27 James WP, Caterson ID, Coutinho W, Finer N, Van Gaal LF, Maggioni AP, Torp-Pedersen C, Sharma AM, Shepherd GM, Rode RA, Renz CL: Effect of sibutramine on cardiovascular outcomes in overweight and obese subjects. N Engl J Med 2010;363:905-917. 